\title{
Quality of life in octogenarians with non small cell lung cancer: the strategic role of video assisted thoracic surgery
}

\author{
N D Vicidomini ${ }^{*}$, G Guggino², G Monaco ${ }^{2}$ \\ From XXIII Annual Meeting of the Italian Society of Geriatric Surgery \\ Lecce, Italy. 2-4 December 2010
}

\section{Background}

The aim of the present study was to assess the surgical approach in octogenarians comparing the benefits of video-assisted thoracic surgery (VATS) with the open thoracotomy and analysing early and long term quality of life (QOL) changes.

\section{Materials and methods}

We reviewed 42 consecutive octogenarians (mean age $82.3 \pm 1.4$ years) with a preoperative FEV1 of $1.5 \mathrm{~L}$ or less who had undergone pulmonary resection for stage I non-small cell lung cancer (NSCLC). Patients were divided into two groups according to surgical approach (VATS group $n=22$; thoracotomy group $n=20$ ) and their postoperative complications and prognoses were evaluated. Quality of life was assessed using Medical Outcome Study Short-Form 36-item Health Survey (SF-36) just before surgery and at 6 and 12 months postoperatively.

\section{Results}

Morbidity rate and postoperative hospital stay were significantly different between VATS and thoracotomy group ( $\mathrm{p}=0.01 ; \mathrm{p}=0.0003$, respectively). A worse decrease in thoracotomy vs VATS group was demonstrated in five domains at 6 months, and in all domains at 12 months of SF-36 questionnaire. The thoracotomy group presented a significant reduction in the dyspnoea index, FEV1 and DLCO at both 6 and 12 months.

\footnotetext{
* Correspondence: vineda81@libero.it

'Unità di Chirurgia Toracia, Università degli Studi di Napoli Federico II, Napoli, Italy

Full list of author information is available at the end of the article
}

\section{Conclusions}

In octogenarians with NSCLC and compromised pulmonary function the long-term survival justifies the operative treatment, and minimally invasive surgical approach enables surgeons to extend pulmonary resection in these high-risk patients if selected appropriately.

\section{Author details}

'Unità di Chirurgia Toracia, Università degli Studi di Napoli Federico II, Napoli, Italy. ${ }^{2}$ Unità Operativa di Chirurgia Toracica, AORN Antonio Cardarelli, Napoli, Italy.

\section{Published: 24 August 2011}

\section{References}

1. Yancik R, Ries LA: Aging and cancer in America. Demographic and epidemiologic perspectives. Hematol Oncol Clin North Am 2000, 14:17-23.

2. Jaklitsch MT, Pappas-Estocin A, Bueno R: Thoracoscopic sugery in elderly lung cancer patients. Crit Rev Oncol Hemat 2004, 49:165-171.

3. Walker WS: Video-assisted thoracic surgery (VATS) lobectomy: The Edinnburgh experience. Semin Thorac Cardiovasc Surg 1998, 10:291-299.

4. Nakajiama J, Takamoto S, Kohno T, et al: Costs of videothoracoscopicsurgery vs open resection for patients with lung carcinoma. Cancer 2000, 89:2497-2501.

5. Gardner RM, Crapo RO: New recommendations for standardizing spirometry. Chest 1988, 93:226-7.

6. Mountain CF: Revisions in the international system for staging lung cancer. Chest 1997, 111:1710-1717.

7. Apolone G, Mosconi P: The Italian SF-36 Health Survey: translation, validation and norming. J Clin Epidemiol 1998, 51:1025-1036.

8. Hayes V, Morris J, Wolfe C, Morgan M: The SF-36 health survey questionnaire: is it suitable for use with older adults? Age Aging 1995 24(2):120-5.

9. Kaplan EL, Meier P: Nonparametric estimation from incomplete observations. J Am Stat Assoc 1958, 53:457-481.

10. Hoekstra HJ: Cancer study in the elderly. Eur J Cancer 2001, 37S:235S-244S.

11. Aoki T, Tsuchida M, Watanabe T, Hashimoto T, Koike T, Hirono T, Hayashi Jl: Surgical strategy for clinical stage I non-small cell lung cancer in octogenarians. Eur J Cardiothorac Surg 2003, 23:446-450.

12. Landreneau RJ, Hazelrigg SR, Mack MJ, et al: Postoperative pain-related morbidity: video-assisted thoracic surgery versus thoracotomy. Ann Thorac Surg 1993, 56:1285-1289.

\section{C) Biomed Central}

(C) 2011 Vicidomini et al; licensee BioMed Central Ltd. This is an open access article distributed under the terms of the Creative Commons Attribution License (http://creativecommons.org/licenses/by/2.0), which permits unrestricted use, distribution, and reproduction in any medium, provided the original work is properly cited. 
13. Dales RE, Belanger $R$, Shamji FM, et al: Quality of life following thoracotomy for lung cancer. J Clin Epidemiol 1994, 47:1443-1449.

14. Zieren HU, Muller JM, Hamberger $U$, et al: Quality of life after surgical therapy of bronchogenic carcinoma. Eur J Cardiothorac Surg 1996, 10:233-237.

15. Sugiura H, Morikawa $T$, Kaji M, et al: Long term benefits for the quality of life after video-assisted thoracoscopic lobectomy in patients with lung cancer. Surg Lapatosc Endosc Percutan Tech 1999, 9:403-408.

16. Walters SJ, Munro JF, Brzier JE: Using the SF-36 with older adults: a crosssectional community-based survey. Age Aging 2001, 30:337-343.

doi:10.1186/1471-2318-11-S1-A65

Cite this article as: Vicidomini et al:: Quality of life in octogenarians with non small cell lung cancer: the strategic role of video assisted thoracic surgery. BMC Geriatrics 2011 11(Suppl 1):A65.

Submit your next manuscript to BioMed Central and take full advantage of:

- Convenient online submission

- Thorough peer review

- No space constraints or color figure charges

- Immediate publication on acceptance

- Inclusion in PubMed, CAS, Scopus and Google Scholar

- Research which is freely available for redistribution

Submit your manuscript at www.biomedcentral.com/submit 